\title{
Mergers and Acquisitions and Multinational Companies: A Review and Research Agenda
}

\author{
Justice Kyei-Mensah $^{1}$ \\ ${ }^{1}$ Business School, Ghana Institute of Management Public Administration (GIMPA), Accra, Ghana \\ Correspondence: Justice Kyei-Mensah, Business School, GIMPA, P. O. Box AH 50, Accra, Ghana. Tel. \\ 233-554-268-519. E-mail: jkyei-mensah@gimpa.edu.gh
}

Received: August 12, 2019

Accepted: September 3, 2019

Online Published: September 8, 2019

doi:10.5539/ijef.v11n10p17

URL: https://doi.org/10.5539/ijef.v11n10p17

\begin{abstract}
We review the theoretical and empirical studies concerned with mergers and acquisitions (M\&A) to evaluate the knowledge in the area and to recommend new areas for future research. Unlike other reviews, we focus on research in finance, accounting, and management literature. While the area of M\&A is well-researched in all three subject areas, to date it is unclear what factors actually drive M\&A decisions and the specific impacts of M\&A deals on shareholder wealth. The core material in the finance and accounting journals tend to provide a quantitative basis for accessing the success or failure of M\&A deals. The management journals tend to explore qualitative aspects of mergers. While financial considerations rely heavily on behavioural considerations for their success, we aim to provide an integrated approach to our review.
\end{abstract}

Keywords: M\&A, ARs, shareholders wealth, multinational firms, OLS, GJR-GARCH, share price

\section{Introduction}

"Global mergers and acquisitions reached an all-time high of $\$ 4.304$ trillion in 2015, beating an earlier record of $\$ 4.296$ trillion in 2007, with about a month to spare, the Wall Street Journal reported .... Cheap debt and investor pressure to outrun a slowing economy pushed companies' decisions to consolidate in the year, according to the Journal" http://www.ibtimes.com/mergeracquisition-activity-hits-record-high-2015report2213166 (accessed on February 9, 2015).

In fact, given the nature of corporate acquisition boom for the past decade insinuates a positive effect on shareholder value. However, there are still unresolved issues. The finance, management, accounting, and economics researchers have not able to provide definitive answers to why mergers occur, whether acquisitions added value to the firm, and acquisition activity differs over time, these are still unanswered will challenge the financial academics. These have spurred ongoing analysis and extension in the existing theories of finance, management, accounting, and economics research literature. These conspicuous characteristics and behaviours of M\&A raise questions about existing theories, for both acquirers and targets, which call for new clarification. There has been much debate on whether M\&A enhances value and whether on balance M\&A are economically beneficial for firms and society as a whole. For example, finance literature suggests that acquisitions did not enhance acquiring firm value as measured by either short-term or long-term performance measures (See e.g. Asquith, 1983; Jarrell \& Poulsen, 1989; Agrawal et al., 1992). Chong et al. (2006) show that merger activities destroy shareholders wealth in aggregate.

Theoretically, under rational conditions, M\&A should lead to an increase in shareholders' wealth which may be captured via the change in abnormal returns (ARs). Despite this view, the empirical results are however not always consistent. For example, finance researchers find that acquirers' abnormal returns ARs around merger announcement are either zero or negative and significant (Goddard et al., 2012; Braga \& Gomes, 2016). In contrast, the ARs of targets are generally positive and significant (see, Danbolt et al., 2016; Gan et al., 2017). Jandik and Lallemand (2017) find that target issue more debt immediately before announcement results significant positive gain to target shareholders, but shareholders of bidder experience negative ARs. While the gains to targets could suggest that they are undervalued before the merger announcement, acquirers do not share in the gains in such mergers unless the deal is settled by means of a share purchase. Indeed, there is a lot of evidence to suggest that shareholders of acquirers do not benefit from the underpricing of targets. So while risk-sharing between shareholders of acquirers and targets can lead to a reduction in systematic risk, uncertainty 
about the share price of acquirers and/or targets can determine the form of payment that is eventually agreed. Long run-studies also take a market-based focus but there are problems with an estimation which we address later.

The accounting literature is not absolved from such measurement difficulties. Research based on the accounting approach relies on the data in the financial reports of the entities. Here, the focus is on the change in shareholder wealth. So researcher compares the difference in the financial performance of the merged entity relative to the combined financial performance of acquirers and targets before the mergers (see Healey et al., 1992; Powell \& Starks, 2006). This approach does not lead to consistent results about the gains arising from merger deals. While it is accepted the finance and accounting approaches are not valuing similar things, there should be some consistency in the direction of the two results. After all, the accounting reports are meant to portray the book valuation of market-based measures although the discretion of managers can affect reported results. Researchers argue that market-based measures such as stock prices are more realistic measures of financial performance as they reflect the more accurately the market's judgment about the bid as opposed to the whether the merged entity will be profitable (see Grinblatt \& Titman, 2002). This view relies on rational behaviour and market efficiency. However, stock prices around merger announcements can be mispriced and may not reflect the intrinsic value of the merged entities (Bi \& Gregory, 2011). From a managerial perspective, the success of M\&A depends on the management skills, insight and the effective decision making to ensure that managers bids are successful at all cost. We explore these issues in this review to present a more coordinated perspective on the literature concerned with M\&A.

While we are not the first to under review of prior work on M\&A it is useful to distinguish our review what those that have been undertaken. Haleblian et al. (2009) sought to integrate the knowledge in the area from management, economics and finance perspective and related areas of accounting and sociology. Tuch and O'Sullivan's (2007) review focused on the short- and long-run performance of firms engaged in M\&A using both the finance and accounting perspectives. Napier's (1989) review takes on a human resource perspective. All these reviews rely on the material before the financial crisis with a limited focus on the associated research methodologies. We partly use these papers as a basis for our review and focus on the interpretations and methodological issues associated with research M\&A studies in the finance, accounting, and management literature. These areas are still being debated on the M\&A literature and have a significant impact on the shareholders' value.

This paper is motivated specifically on the question of what explains the phenomenon of M\&A, why firms engage in $M \& A$, whether acquisitions added value to the firm, issues around the announcement of M\&A to give effect to the determination of the ARs, estimation methods, and methodological approaches. To our best knowledge, this is the first under review to consider finance, management, accounting and economics literature and to suggest a strategy for mitigating its consequence on M\&A. This literature review develops illustrative frameworks that incorporate these different categories of contextual variables that influence the M\&A process. In this review, we outline the gaps by developing a comprehensive theoretical framework in the M\&A literature. We specifically contribute to these gaps, both theoretically and in an empirical perspective and outline several future research directions.

The next section discusses the methodology in this study. Section three critically review the empirical literature of mergers and acquisitions. Section four bring all those perspectives together and recommend the areas for further research. We conclude in the final section.

\section{Methodology}

To start with, we searched eminent peer-reviewed academic journal in the Elsevier, Emerald Full Test, Routledge (Taylor and Francis Group), JOTOR Business, and Direct Science databases. Our quantitative research in the field of finance, management, accounting and economics literature from 1992 to 2017, was restricted to samples of articles published in most influential academic journals. These prominent academic journals are shown in Table 1. The next step is to search of titles and abstracts of these journals (Journal of Finance, Journal of Management, Journal of Accounting, and Journal of Economics) on the keywords: merger, acquisition, acquired, acquiring and mergers and acquisitions $(M \& A)$ and coded the key contextual variables. These searched generated 256 articles. We then narrow our search to 92 articles, bearing in mind the topic under consideration. These journals representing the most cited articles in a scholar and profoundly methodological in orientation. It is interesting to know that most of these articles were published in finance and management journals. Note that, research interest in mergers and acquisitions in the finance field remains most popular, amongst all the journals researched, follow by management field. 
The next stage of the methodology is to conduct a co-citation analysis between articles contributing to the identical research field to reveal its knowledgeable form (Shafique, 2013). To this end, we used a robust methodology based on the bibliometric method of co-citation analysis to ensure multidisciplinary review of the field of finance, management accounting and economics. Co-citation analysis, an approach established by bibliometric research, as prominent literature for cross-disciplinary ideas. In his paper, Osareh, 1996, p. 149 states that citation analysis is a major bibliometric approach. Bibliometric is increasing used to measure the impact of research. We use the methodology of SciVal Spotlight web-based application developed by Elsevier Publication. This approach is based on co-citation analysis. We then choose journals that are mostly in fields of finance, management and accounting and economics.

Table 1. List of journal used for the articles

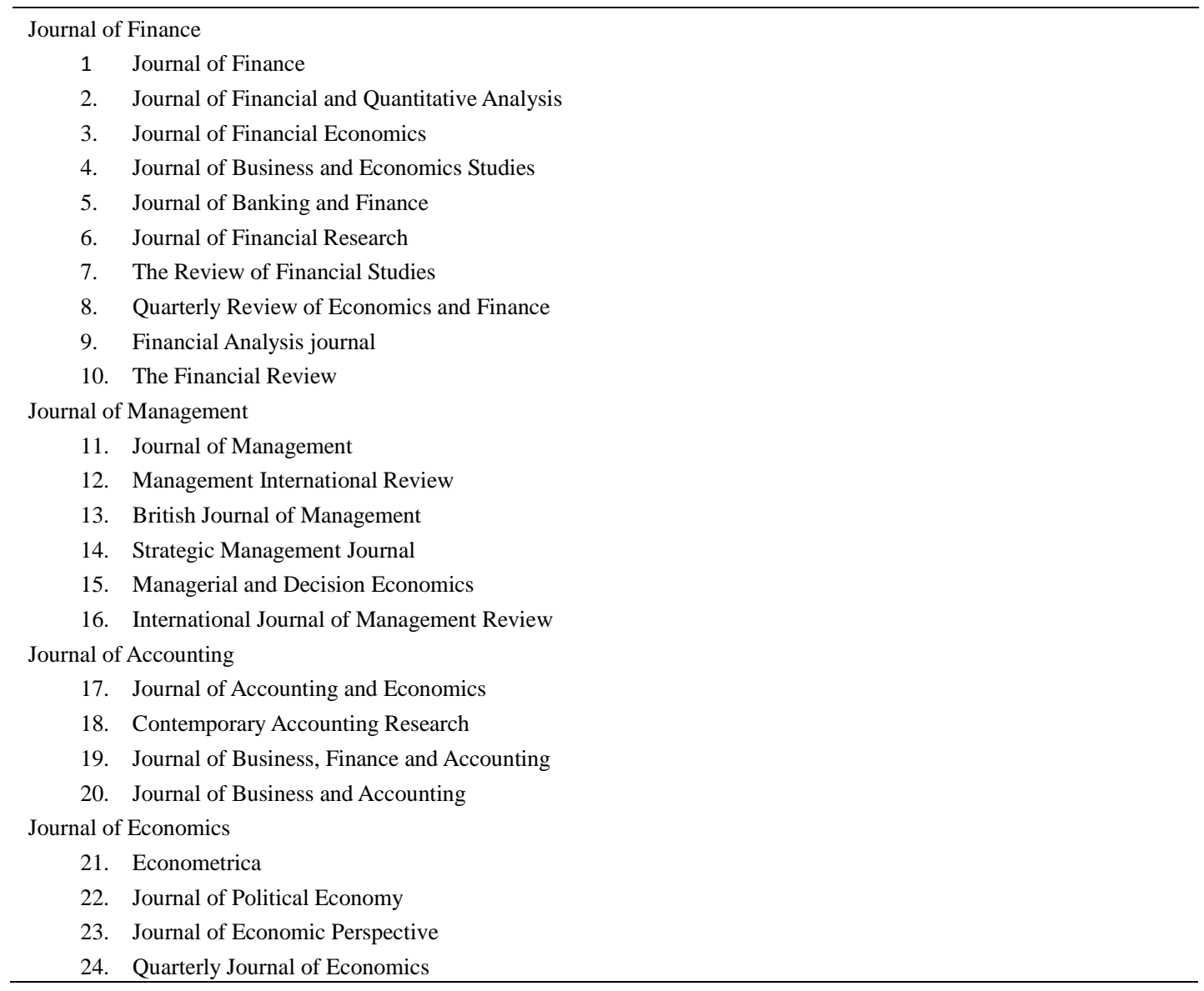

\section{Review of the Literature}

Several theories have been advocated in the literature to provide potential explanations for the rationale behind the corporate acquisition. To date empirical evidence is inconclusive on the underlying factors motivating M\&A activities and whether M\&A increase shareholders wealth as prior researchers almost universally find negative returns for bidding firms. The reasons for the failures of corporate acquisition activities can be attributed to inefficient management, poor governance, innovations in financing, global competitive pressure, and relocation of new market opportunities. Some studies have shown that M\&A manifests itself as a strategic point for restructuring, which is seen as a turning point for companies to maximize the potential for economic benefit. Acquisitions with the objective of increasing shareholders' wealth may risk being less successful than anticipated. (Chatterjee, 2011; Kemel, 2011; Yen \& Andre, 2010; Tuch \& O'Sullivan, 2007) find either zero or negative ARs for shareholders of acquiring firms. All in all, the general result is that the acquirers' ARs are not positive. On the other hand, empirical studies universally documented positive ARs for target firms on the announcement of M\&A (Jandik \& Lallemand, 2017), suggesting that all of the gains go to the target shareholders. Zander and Zander's (2010) describe post-acquisition integration efforts as 'grey box'. In an acquisition, much information 
and possibilities arise through interaction between the acquired and acquiring firms. Zander and Zander argue that 'the acquiring firm will not know everything they would like to before its managers and employees begin to unpack the target acquisition'. Zander and Zander (2010) suggest that no due diligence in the world will, a firm makes, it is impossible to know everything about the target in advance. Sometimes certain things may not know, but only become exposed steadily through the ongoing process of common and reciprocal collaborations. This argument means that in the world of acquisition due diligence is important but whatever processes that may apply it is impossible to know the secrecy of the target in advance,

Why firms engage in $M \& A$ - There is long-standing debate why M\&A occur. To address this question, we need to understand and appreciate the economic and social benefit perspective that M\&A brings. Following this logic, research indicates that mergers can create synergies based on growth strategy, the economics of scale and scope, and other benefits to maintain competitive advantage (Uhlenbruck et al., 2017). Reynolds and Teerikangas (2016) indicate that firms use M\&A for strategic expansion and to develop new skills and capabilities and the potential competitive strengths an acquirer can derive from M\&A. Meyer (2018) also indicate that these acquired assets are strategic and they strengthen the capabilities of the acquirer, providing advanced technologies or international brand names that strengthen the firm's competitive position and transform their capabilities. Operating capabilities of the two firms will lead to economies of scale. Lewis and Webb (2007) observed that cost of synergies arising from the two companies would lead to overall scale economy changes and the return of higher scale emerges. This suggests that as firms engage in merger activity, there is a possibility that both acquired and acquiring shareholders might measure gains through the deal. Therefore, it is imperative that firms operating below capacity and with the potential to achieve economies of scale should engage in the acquisition, and greater profitability should contribute to maximizing shareholder wealth. Behr and Held (2011) suggested that the main motive for mergers might be the achievement of a scale of economies or market power.

What explains the phenomenon of $M \& A$ - The motive of M\&As may be the outcome of firm gaining access to technology, by permitting technologically greater firm prospects to exploit its technology (Datta \& Puia, 1995). Indeed, most firms engage in a merger due to the acquisition of technology as the principal reason behind deals. The deal-making process will look dramatically different as innovations in analytical devices continue to increase. From the point of view acquisition, the strategic objective of the acquiring firm to use the technology assets now rank number one as a strategic driver of M\&A deals, and most considered as a key factor for industry convergence activity. This argument climax the importance of strategic assets as the crucial determinants for acquiring firms who appear to be aiming at the target firms through the inert route to overcome their scant product development capabilities. Bena and $\mathrm{Li}$ (2014) suggest that a merger motive of both acquired and acquiring was to access each other's technology assets and skills. Given the theoretical importance of acquisition, several technologies of the target firm seem valuable to the acquiring firm, and vice versa, generating the deal. Other finance scholars have proposed that enhancement in post-merger innovation production befalls through technological synergy. Ahuja and Katila (2001) find that acquiring firms' technological relatedness is connected with enhanced innovation output in the chemicals industry. In this regard, the acquiring firms analyze these technological assets, from target firms, from a theoretical point of view, and how these capabilities must impact the acquiring firm performance; each of the acquired technological assets plays a dominant role in shaping these capabilities of the acquiring firms. The overall benefit of acquiring firm complete control of arises from asset possessed and capacity to obtain opposite assets of the target.

Multinational enterprises acquisition - Companies acquired other companies internationally have witnessed an enormous increase in the past and it will continue to increase in the years to come. These cross-border acquisitions by multinational enterprises (MNEs) have now become a fashion as some firms expand to enjoy economies of scale and scope, internationalization, diversification, synergies and to maximize economic potential. We argue that cross-border acquisitions motives stem from income generation and that there will be a positive relationship between cross-border acquisitive and income generation.

Morck and Yeung (1992) in Wu et al. (2016) indicate that international diversification may perhaps not able to explain the reasons for value creation, however, internalization may aid companies to create value through judicious use of their intangible asset. A study conducted by these authors on the impact of firms' overseas M\&As on stock price, indicates that overseas M\&As by firms with intangible asset created significant ARs. Similarly, a study conducted by Marr Jr, et al (1993) support internalization hypothesis and concluded that overseas M\&As produce firm value through synergy as a result of applying intangible assets. Moreover, cross-border acquisition leads to superior economics of scale when their tangible and intangible assets are set on the world stage. Scholars have argued that MNEs cross-border expansions are means of entry into the foreign market thereby increasing the growth and returns generations prospects than the domestic market. Other scholars stated that cross-border 
acquisitions are mostly commenced to manage resilient international competition in the foreign market. To an enormous extent, this has occurred as consequences of MNEs attempts to source inputs discover production anyplace in the world where costs are low and return higher (Eun \& Resnick, 2009). For instance, it has frequently become problematic to link a product with a particular country origin. This has happened as a result of MNEs sought to minimize cost as well as maximize their returns, by setting production anywhere in the world where production costs are low and profit higher. For example, more Western European firms established firms in Eastern European countries to minimize the cost of production and increase profit potential. MNEs are taken to cross-border acquisition due to resource and technology. The cross-border acquisition by the acquiring company the right to use the new capabilities and facilities the acquisition of transfer a knowledge, resource and technology (Boateng et al., 2008). The means that the new acquisition of knowledge, resource and technology will build acquiring firm's new capabilities which in turn increase its return generation. The prolong perception held by MNEs firms from the developed world that emerging economies are underdeveloped therefore emerging market are for MNEs firms from the emerging market cannot be no longer sustained. The emerging market tries to break up dependence and by catch-up in technology and knowledge to stand alone like the MNEs firm from the developed world by demonstrated mammoth economic strength (Lall, 1983; in Wu et al., 2016). This means that MNEs from the emerging market no depend on formerly technology and knowledge instead gain technology and knowledge through international expansion and therefore market economics gain significantly from acquisitions into emerging markets. In general, research on international diversification has shown that as the firm diversifies, the risk of a portfolio is reduced or disappears, and the amount of return increases. This allows investors the opportunity to expand their business on a large scale and across the geographical spectrum. The risks return tradeoff, in which investor want to achieve the utmost possible return for the level of risk that they are eager to take. Cross-border acquisition forbidding company tends to reduce risk and the volatility of cash flows through geographical market diversification (Davis et al., 1991; Datta \& Puia, 1995). Scholars argue that international market diversification of assets from countries with business cycles uncorrelated with the US business cycles tends to lower the portfolio's responsiveness to the market movement (Eun \& Resnick, 2009). In the long run, international diversification portfolios tend to do well than entirely domestic portfolios. Nevertheless, in the short run, international diversification portfolio may do well or badly. Synergy theory hypothesis that cross-border M\&As take place due to the economic benefit of amalgamation resulting mergers. Cooke (1988) suggests that operation synergies in cross-border acquisitions can take the form of economies of scale and scope subsequent the companies able to fortify a cost advantage above its international opponents. Cross-border acquisitions by MNEs are found to be higher significant increase return on shareholder wealth effects relative to domestic acquisition (Cheng \& Zhang, 2006).

However, these motives of cross-border acquisitions might not be achieved due to some potential challenges which are detrimental to multinational enterprise firm's encounter. Also, the literature on the cross-border acquisition pinpoints a number of drawbacks that are 'associated with the acquisition that the MNEs encounter in their dealings. Political risk stems from that fact that the country where the MNEs established the firm the government may change the laws the foreign company may not have effective recourse. A case in point was in 1992 when Enron Development Corporation after they have signed a contract to build India biggest Power plant, however, the contract was then camouflaged after three years the when India government decided that India does not need such a project after Enron had spent $\$ 300$ million (Eun \& Resnick, 2009). This occurrence demonstrates how inconvenience of enforcing contracts in overseas countries. Cross-border acquisitions are tantamount to face foreign exchange risk. These MNEs firm are potentially endangered to foreign exchange risk as they transact their day to day activities that they would not generally come across in entirely domestic operations. Furthermore, market imperfection theory was identifying as the major drawback that cross-border acquisitions encounter. Today, the world economy is much integrated than three decades an ago, yet a lot of economic barriers like information asymmetry, legal restrictions and discriminatory taxation just to mention few, stagnant free movement of people, capital, goods and services between countries (Eun \& Resnick, 2009). As results of market imperfection, a company may decide to institute assembly facilities to avoid these barriers. For example, VALCO an American Aluminum Company decided to establish facilities in Ghana just to circumvent these barriers. Adding their voice to imperfection or inefficiencies, Fatemi and Furtado (1984) indicated that cross-border acquisitions might allow acquiring firm to take advantage of the imperfections or inefficiencies in the marketplace for corporate control in overseas markets.

Based on the review, many arguments have been put forward for or against cross-border acquisitions. Some researchers find that cross-border acquisitions do not create value for acquiring firm shareholders. Ideally, others argued that cross-border acquisitions indicate an amount of potential economic benefits for acquiring firms. From forgoing arguments, we think that cross-border acquisitions by MNEs have potential to increase return 
generations of acquiring firms and managers undertake such investments prospects if they think it will bring synergies to both firms.

Test statistic of statistical significance - One problem of the event studies is the volatility of the ARs clusters around the event date and this clustering can lead to over-rejection of the null hypothesis of zero ARs. Kolari and Pynnonen (2010) amended Boehner et al. (1991), hereafter, the BMP t-statistic and many other tests to develop different versions of some of the existing tests. They find that their amended-BMP t-statistics perform better with the event-induced volatility and cross-correlation than their other amended tests (Kolari \& Pynnonen, 2010). Another issue with the test statistics in the event studies is the cross-dependence. Mitchell and Stafford (2000) argue that event studies that pay no attention to cross-dependence in data will generate overstated test statistics and will lead to severe misspecification. Accordingly, some prominent scholars who are known in the literature add their voice to the issue of test statistics of statistical significance of ARs. These previous studies argue that the test statistics of long-run ARs accommodating biased estimates of standard errors and that can lead to inaccurate inferences (see e.g. Barber \& Lyon, 1997; Kothari \& Warner, 1997). These two studies suggest that the test may be flawed or incorrect. In this regards, Fama (1998) proposes a calendar-time portfolio approach, and argue that the buy-and-hold methodology exacerbates any bad model problems and disregards possible cross-sectional correlations of event-firm ARs, However, Loughran and Ritter (2000) disprove the calendar-time portfolio approach of Fama, and argue it fails to identify abnormal performance associated with event studies that are clustered across time. Due to important methodological implications, Savor and Lu (2009) recommended that both the event time and calendar-time methodologies should be applied

Model approaches - The literature review shows that the best model in estimating the ARs for shareholders are inconclusive and findings are difficult to compare as the models still vary widely. Despite extensive research on the event studies in estimating the ARs, there are still problems as to what best research model to be used. For instance, Fama-French (1996) suggest that the choice of the benchmark can have an important impact on the scale of ARs on event studies. Failure to adopt an appropriate model can lead to under or overestimation of the ARs. The review shows that a significant number of researchers employed different statistical methodologies. Overall, prior empirical studies do not provide clear evidence to show which of the model best estimates ARs. Comparisons are difficult across prior studies. Thus different models could provide different results. This infirmity of prior studies is somewhat worrying as to how best could be resolved. Potential implications of these arguments are that other factors might have contributed to their difference in findings.

Inefficient management - The inefficient management hypothesis suggests that underperforming management will be removed and replaced through a takeover. The general perception of this hypothesis is concerned with asset management and its efficiency. Inefficient management pertains to underutilization of firm resources to generate output. Empirical studies show that an indication of inefficient management is when the assets of the company are not fully and efficiently utilized. Rege (1984) in his studies noted that "in some cases if a lower activity is perceived as a sign of inefficient management, a takeover may be able to make the firm more profitable". North (2001) also tested this hypothesis. He said "since this argument assume that takeovers partially serve to replace inefficient management". Therefore the issue to be examined here is whether a firm would be acquired due to its relatively poor financial performance in terms of efficiency as compared to non-acquired. In pursuit of their business, acquiring firm acknowledge mismanagement in a target firm and attempt a takeover. This theory suggests that inefficient management will be removed and replaced. An acquiring firm serves to solve inefficiency in the target's management which will eventually create value in the target firm.

Stock market size effect - One of the essential stock market anomalies well-known in the M\&A literature is the size effect. A lot of theoretical explanations have been put forward in the literature to explain this anomaly. The finance theory suggests that firm size affect the performance of acquisitions. The empirical evidence proposed in the literature to explain this phenomenon is mixed. Healy et al. (1992) found that large mergers produced positive post-acquisition accounting performance which increased asset productivity. Moeller et al. (2004) examined firms' size and gains from acquisitions on the announcement for both target and bidding firms. The small acquisitions by small acquirers' ARs are positive on announcement relative to large acquisitions by large acquirers' ARs are significant negative on the announcement. They observed that small firms gain substantially when they announced the acquisition and that the size effect reversed hypothesis does not hold. The study suggests that large firms pay higher acquisition premiums relative to small firms on acquisition and also large firms enter acquisition with negative synergy gains. Other empirical studies have supported the notion that small firms' stock returns on announcement exceed big firms. Dimson and Marsh (1999), Reinganum (1999), Van Dijk (2007) and Andrikopoulos et al. (2008) have concluded that small firms outperformed large firms. However, some researchers have disproved the size effect hypothesis that small firm on acquisition outperform big firms, 
but rather attributed it to other factors. Wang (2000) was of the view that data truncation and volatility might have caused the size effect. Lo and Mackinglay (1990) suggested that the small size effect might happen due to methodological and data snooping. The size effect hypothesis is attributed to a risk factor and that most small firms are fundamentally riskier than most big firms and therefore will generate higher returns compared to relatively big firms (Berk, 1995).

Defences against Acquisition - Companies might institute defence tactics if they are vulnerable to be taken over. The purpose of defences against acquisitions is to salvage the interest of the managerial self-interest at the expense of the shareholders. Target management might apply the excessive use of different defences' strategies which will make it difficult to deal with and critically out of touch with realities. Over the years, there has been an increased number of M\&A but some mergers have been unsuccessful. This is due to some acquisition defences that target management must apply in their attempt to overpower the acquiring firm management. The defiance might help the target to perform better on its own and to seek to entrench itself against loss of power if a merger takes place. A plethora of empirical studies examining defence strategies have shown evidence that shareholders interest must be taken into consideration. Sarig and Talmor (1997) indicated that defensive measures have a tendency to increase shareholders' wealth. If directors agree with the acquisition, they must demonstrate that the price was fair to shareholders and that was the best price that could be achieved. The dominance of defence measures indicates that shareholders regard those measures as wealth-creating. Similarly, poison pills are designed by directors without approval from shareholders to make the acquisition extremely expensive and can be a very successful way to discourage acquirers. Comment and Schwert (1995) proposed that poison pills tended to increase takeover premiums without decreasing takeover likelihood. However, Field and Karpoff (2002) findings were pointing to the north, by establishing that poison pills and takeover defences decrease takeover likelihoods without any compensating increase in takeover premiums. Generally speaking, self-interest behaviour increase acquisition activity - value-enhancing and value-destroying has increased in many years.

Deal type - The significance of corporate acquisition has led most empirical research to focus the firm's performance with merger or tender offers. Merger normally takes place between the acquiring firm and target firm to come together under one umbrella of management.

Managers of both firms undertake a due diligence process to ensure that the transaction is beneficial to both companies, which the shareholders vote on. The term tender offer, however, denotes a type of takeover bid through a public or open offer by an acquirer to all stockholders of a publicly traded corporation to tender their stock for sale at a particular price or time. Travlos (1987) suggested that mergers are mostly common stock exchange offers whilst tender offers are typically cash offers. According to Walker (2000), tender offer signifies inefficient target management where the offer is made directly by the acquiring firm to shareholders of the target firm when the firm's board of directors disagrees with the acquisition. Walker (2000) reported that acquirer firm shareholders' normally earn higher returns following tender offers and cash offers relative to stock offers and merger that generated lower returns. To persuade or induce the shareholders of the target firm to sell, acquirers normally offer a price that might include a premium which is above the current market price of the target firm's shares. Bruner (2002) found that tender offer creates more value than the merger for bidder firms' shareholders as a result of negotiating with target shareholder directly by bypassing management. Empirical evidence has shown that in tender offer targets shareholders' wealth substantially increases (see e.g. Jensen \& Ruback, 1983; Lang, Stulz, \& Walking, 1989; Berkovitch \& Narayanan, 1993).

\section{Method of payment - Prior studies have suggested that there is a correlation between stock prices}

on announcement and method of payment. On announcement, acquirers are more likely to finance the acquisition with stock rather than cash when their shares are overvalued (Travlos, 1987). It seems therefore that the empirical evidence maintains the view that acquirer's firm is overvalued and that negative information or impression might have an effect on the stock prices of the acquirer, consequently leading to a decline on announcement period stock returns. Loughran and Vijh (1997) found evidence in support of cash tender offers but not for stock mergers. Fama-French (1992) found that bidders in cash tender offers earn significant positive ARs but bidders in stock mergers suffer significant negative ARs. This happens because, the method of payment may indicate important information to the market, given the information asymmetry that managers of investment companies have more knowledge about the companies' prospects will finance the acquisition at the best interest of the shareholder. This argument suggests that bidders are likely to finance with cash when their share is undervalued and pay by stocks if their share is overvalued; consistent with asymmetric information hypothesis and the market underreaction hypothesis. Myers and Majluf (1984) suggest that high value acquires tend to make a cash payment to seal the deal. On the other hand, bidders will make cash payment when there is high 
uncertainty about their market value. Kyei-Mensah et al. (2017) find that acquirers' cumulative abnormal returns are positive and significant when cash financing is made. In the context of acquisitions, the payment hypothesis implies that acquiring firm prefers to pay for their acquisition with cash. This argument suggests that there is strong evidence in support of cash payment than a stock payment.

\section{New Directions for Future Research and Contributions to Knowledge}

Perhaps what we have discussed here amount to a few of the diverse contributions, each punitive methodology has made significant developments, since most of the important issues were tackled, that antagonize the industry. This paper presents a review of empirical evidence of M\&A deals on shareholders wealth. The finance, management, accounting and economics researchers have used a different set of methodologies to investigate acquisition performance. In the literature, several theoretical and empirical arguments have been advocated to account for the acquisition performance and the strength and weakness of various model specifications in the realm of M\&A. Despite comprehensive discussions and empirical work the literature has not to be able to provide a meaningful basis to analyze $M \& A$, why mergers occur, acquisition activity differs over time, and what proper procedure should be followed. These studies show that there are some unresolved issues, a challenge that remains for the finance, management and accounting academics researches. Based on the review outlined above, we proposed new directions for future research, are not limited to, nevertheless, they signify our perceptions of most researchers should look into these seven sets of questions.

First, the implication of the small sample size - The apparent contradiction in results reported by these researchers could be attributed to the underlying small sample size selected. Where the data set is extremely small, this could easily impact the results of acquisition performance. Small sample size has been found to contribute to the mixed results intrinsic in acquisition performance studies (Frank et al., 1991). The review shows some studies have used relatively small sample size in their analyses. For example, Adnan and Hossain (2016) sample size of 50 targets and 50 acquirer firms to test, the impact of M\&A announcement of the firms' stock price may be insufficient to estimate the ARs. My first research question is how the sample size influences the result given the relatively low sample size. The important methodological implications arising from this review shows that a significant number of researchers used a small sample size. In this regards, future research should use a large sample size and multivariate framework, improve reliability, validity, and accompaniment quantitative studies with qualitative research.

Secondly, how constituency influences the corporate restructuring - To date, not much research had been done or there is no work regarding how the acquisition affects various constituency groups of both the acquiring and the target firms. The opportunities for potential research in the many constituencies' disciples are plentiful. Because there are many constituencies; employees, creditors, stakeholders, the financial community affected by any particular change in corporate restructuring, there should be further study to ascertain the costs and benefits of M\&A. Not much research had been done in those groups to examine how M\&A influences those constituencies especially firms creditors, financial institutions, and customers. Therefore the opportunities for potential further research in the constituencies' area are plentiful. We recommend that researchers focus on acquisition influence these many constituencies. We think that opportunities exist for supplementary studies to explore how M\&A affect firms' creditors.

Thirdly, finance and accounting approach not valuing similar thing - Our review shows that a significant number of researchers used finance and accounting approaches in acquisition-related studies. While it is accepted the finance and accounting approaches are not valuing similar things, there should be some consistency in the direction of the two results. After all, the accounting reports are meant to portray the book valuation of market-based measures although the discretion of managers can affect reported results. Researchers argue that market-based measures such as stock prices are more realistic measures of financial performance as they reflect the more accurately the market's judgment about the bid as opposed to the whether the merged entity will be profitable (see Grinblatt \& Titman, 2002). This view relies on rational behaviour and market efficiency. On other hand, finance researchers stress accuracy and descriptive statistics, as a technique exhibit statistically significant courtesy. In the end, these two approaches do not seem to produce the same results or evidence - theoretical framework verse empirical framework. On the balance, we believe that the discrete disciplines, the finance approach could be better in term accuracy and descriptive statistics, as a technique exhibit significant or not significant to contribution and methodologies for potential future research.

Fourth, there are no consensuses about which of the specific estimation method and model that best to be applied - The review revealed that a significant number of researchers employed different statistical methodologies to link the models of acquisition performance adopted in the finance and accounting in their 
studies. One important point to remember is that methodology is an integral part of the research and that it is an essential element that determines the results of a research. It should be noted that these research methodologies are associated with different methodological problems. Hence different methodologies would produce different results leading to different conclusions. The review shows that previous researchers often use standard OLS estimation method to estimate the ARs. In order to access the effects of different estimation methods on the ARs, we suggest that further research should re-estimate the model using the (asymmetric) GJR-GARCH estimation method. The use of different estimation methods might provide explanations about ARs on the announcement of M\&A. The use of the GJR-GARCH method leads to greater estimation efficiency relative to the OLS method (see, Corhay \& Rad, 1996). "Our overall reviews strongly support the view that the ARs are affected by the choice of CAPM and the estimation method. These factors impact the ARs in addition to the usual financial characteristics of targets and acquirers. Our preferred estimation method is the GJR-GARCH-M method as it generates more consistent results" (Kyei-Mensah et al., 2017).

Fifth, the implication of the combined firms' performance - The next research question should look into the combined firm' performance on cross-disciplinary perspectives rather than acquiring firm performance to see how it influences the post-acquisition performance, whether the negative long-term performance is due to the acquisition of the target firm. Over the years corporate restructuring using M\&A related issues often concentrate on the performance of acquiring firms without taken into consideration the performance of target firms after the acquisition event. As a result, scores of empirical studies often use only the long-term acquirer's performance measure, totally disregarding the significant contributions made by the target firms to the combined firm's performance. Further research is recommended to look at the target firms' contribution to the post-acquisition performance of the acquiring firms to see whether the negative long-term performance of the acquiring firm is due to the acquisition of the target firm.

Sixth, future research should use the same period - Our review further shows that most of the studies on M\&A activities focus on a relatively short period, with the exception of a few researchers who have extended their analysis above ten years. Hogholm (2016), Gan et al. (2017) and Danbolt et al. (2016) have extended their analysis for a period of 13, 20 and 23 years, respectively. Tuch and O'Sullivan (2007) described a short time as the days or months around the announcement of the bid, whilst long-time denotes as periods of month or years. Given the short-term and long-term periods, comparisons between the two periods; there should be some consistency in the two results. In this regards, the periods being compared should have been the same. It will be prudent if the short-term period is used or long-term period is applied, that cannot distort the results of comparisons, regardless of whether cross-sectional or times series analysis is used. We believe that sampling periods create research prospects concerning the generalizability of results from one situation to another in the acquisition.

Seventh, the implication of the direct measures of slack resources affects the M\&A characteristics - The next set of the research question is how slack resources influence the M\&A characteristics. With regards to size and slack, because there is a close relationship between size and slack resources, future research should consider using direct measures of slack resources to identify the effect of slack on the M\&A characteristics.

\section{Conclusion}

This paper was designed to critically review the empirical existing literature in the area of shareholders wealth associated with M\&A. The review was structured in such a way that it covered those important areas under $M \& A$, specifically why $M \& A$ occur, what explains the phenomenon of $M \& A$, and methodological approaches. The review has also shown that previous studies have not yet able to document consistent results concerning ARs for acquirer firm shareholders after the announcement. Potential implications of these arguments are that other factors might have contributed to their difference in findings. One important conclusion from this reviewed was that the literature generally had not been able to say which methodology is the best to be used to examine the wealth effect of M\&A. This review is significant as they provide managers, investors, and regulatory bodies the opportunity to understand the effect of M\&A on the impact of share prices as well as shareholders. One remarkable question we would like to ask is that: how can the manager of acquiring firms embarked on acquisitions that do not benefit them? Meyer (2018) suggests that we lack understanding of how M\&A implement their strategies, hence, we expect to see value enhancement. At the very least, global economic uncertainty will push companies' decisions to M\&A in the years to come. The recent developments in the financial market lower volatility, as volatility index in recent times traded as its bottommost historic level, due to an economic downturn. This may prove the increased resiliency of companies to circumnavigate through a key global economic shift. Despite these compressive discussions, there are still unanswered issues in terms of the best technique to use in estimating shareholders' wealth and why M\&A activities differ over time these will 
challenge the financial academics.

\section{References}

Adnan, A., \& Hossain, A. (2016). Impact of M\&A announcement on acquiring and target firm's stock price: An even analysis approach. International Journal of Finance and Accounting, 5, 228-232. https://doi,org/10.5923/j.ijfa.20160505.02

Agrawal, A., Jaffe, J. F., \& Mandelker, G. N. (1992). The post-merger performance of acquiring firms: A reexamination of a anomaly. Journal of Finance, 47, 1605-1621. https://doi.org/10.1111/j.1540-6261.1992.tb04674.x

Ahuja, G., \& Katila, R. (2001). Technological acquisitions and the innovation performance of acquiring firms: A longitudinal study. Strategic Management Journal, 22, 197-220. https://doi.org/10.1002/smj.157

Alexandridis, G., Antoniou, A., \& Zhao, H. (2006). Valuation effects of short sale constraints: The case of $\begin{array}{lllll}\text { corporate takeovers. European Financial Management, } & \text { 12(5), }\end{array}$ https://doi.org/10.1111/j.1468-036X.2006.00275.x

Andrikopoulos, P., Daynes, A., Latimer, D., \& Pagas, P. (2008). Size effect, methodological issues, and risk-to-default: Evidenc from the UK stock market. The European Journal of Finance, 14(4), 299-314. https://doi.org/10.1080/13518470802042070

Asquith, P. (1983). Merger bids, uncertainty, and stockholder returns. Journal of Financial Economics, 11, 51-83. https://doi.org/10.1016/0304-405X(83)90005-3

Avramov, D., \& Chordia, T. (2006). Asset pricing models and financial market anomalies. The Review of Financial Studies, 19(3). https://doi.org/10.1093/rfs/htj025

Baillie, R. T., \& Bollerslev, T. (1989). The message in daily exchange rates: A conditional-variance tale. Journal of Business and Economic Statistics, 7, 297-305. https://doi.org/10.2307/1391527

Banz, R. W. (1981). The relationship between return and market value of common stocks. Journal of Financial Economics, 9, 3-18. https:/doi.org/10.1016/0304-405x(81)90018-0

Barber, M. B., \& Lyon, D. J. (1997). Detecting long-run abnormal stock returns: The empirical power and specification of test statistics. Journal of Financial Economics, 43, 341-372. https://doi.org/10.1016/80304-405X(96)00890-2

Barberis, N., Huang, M., \& Santos, T. (2001). Prospect theory an asset prices. Quarterly Journal of Economics, 116(1). https://doi.org/10.1162/003355301556310

Barberis, N., Shleifer, A., \& Vishny, R. (1998). A model of investor sentiment. Journal of Financial Economics, 49, 307-343. https://doi.org/10.1016/0304-405x/98/\$19.00

Behr, A., \& Heid, F. (2011). The success of bank mergers revisited. An assessment based on a matching strategy. Journal of Empirical Finance, 18(1), 117-135. https://doi.org/10.1016/j.jempfin.2010.08.006

Bena, J., \& Li, K. (2014). Corporate innovations and mergers and acquisitions. Journal of Finance, 69(5), 1923-1960. https://doi.org/10.1111/jofi.12059

Ben-Amar, W., \& Andre, P. (2006). Separation of ownership from control and acquiring firm performance: The case of family ownership in Canada. Journal of Business Finance \& Accounting, 33(3\&4), 517-543. https://doi.org/10.1111/j.1468-5957.2006.00613x

Berk, B. J. (1995). A critique of size-related anomalies. The Review of Financial Studies Summer, 8(2), 275-286. https://doi.org/10.1093/rfs/8.2.275

Berkovitch, E., \& Narayanan, P. M. (1993). Motives for takeovers: An empirical investigation. Journal of Financial and Quantitative Analysis, 28(3). https://doi.org/10.2307/2331418

Bi, G. X., \& Gregory, A. (2011). The stock market has driven acquisitions versus the Q theory of takeovers: The UK evidence. Journal of Business and Accounting, 38(5\&6), 628-656. https://doi.org/10.1111/j.1468-5957.2011.02234.X

Boateng, A., Qian, W., \& Yianle, Y. (2008). Cross-border M\&As by Chinese firms: An analysis of strategic motives and performance. Thunderbird International Business Review, 50(4), 259-70. https://doi.org/10.1002/tie.20203

Boehmer, E., Masumeci, J., \& Poulsen, A. B. (1991). Event-study methodology under conditions of 
event-induced variance. Journal of Financial Economics, $253-272$. https://doi.org/10.1016/0304-405x(91)90032-F

Bruner, R. F. (2002). Does Mergers and Acquisition Pay? A survey of evidence for the decision maker. Journal of Applied Corporate Finance, 12, 48-68.

Campa, M. J., \& Hernando, I. (2006). Mergers and Acquisitions Performance in the European Financial in Industry. Journal of Banking \& Finance, 30, 3367-3392. https://doi.org/10.1016/j.jbankfin.2006.06.006

Carhart, M. M. (1997). On persistence in mutual fund performance. Journal of Finance, 52, 57-82. https://doi.org/10.2307/2329556

Chandra, R., \& Balachandran, B. V. (1990). A synthesis of alternative testing procedures for event studies. Contemporary Accounting Research, 6, 611-640. https://doi.org/10.1111/j.1911-3846.1990.tb00778.x

Chatterjee, R. (2011). Mergers and acquisition: The impact of a share price. Journal of Institute of Management Study, 11, 123-148.

Chen, H., \& Singal, V. (2004). All things considered, taxes drive the January effect. The Journal of Financial Research, 27(3), 351-372. https://doi.org/10.1111/j.1475-6803.2004.00095.x

Cheng, H., \& Zhang, K. (2006). Wealth effect analysis of cross-border M\&A by Chinese listed companies. Journal of World Economy, 12, 74-80.

Chong, B. S., Liu, M.H., \& Tan, K. H. (2006). The wealth effect of forced bank mergers and cronyism. Journal of Banking and Finance, 30, 3215-3323. https://doi.org/10.1016/j.jbankfin.2005.12.004

Co-Citation Analysis: The Methodology of SciVal Spotlight. Retrieved from http://www.americalatinaElsevier.com/sul/pt-br/scival/pdf/Co-Citation_Analysis_SciVal_Spotlight.pdf

Comment, R., \& Schwert, G. W. (1995). Poison or placebo? Evidence on the deterrent and wealth effects of modern antitakeover measures. Journal of Financial Economics, 39, 3-44. https://doi.org/10.1016/0304-405x(94)00823-j

Conrad, J., \& Kaul, G. (1998). An anatomy of trading strategies. The Review of Financial Studies, 11(3), 489-519. https://doi.org/10.1093/rfs/11.3.489

Cooke, T. (1988). Intertional mergers and acquisitions. Oxford, Blackwell.

Corhay, A., \& Rad, A. T. (1996). Conditional heteroskedasticity adjusted market model and an event study. Quarterly Review of Economics and Finance, 36, 529-538. https://doi.org/10.1016/s1062-9769(96)90050-2

Danbolt, J., Siganos, A., \& Tunyi, A. (2016). Abnormal returns from takeover prediction modeling: Challenges and suggested investment strategies. Journal of Business Finance \& Accounting, 43(1\&2), 66-97. https://doi.org/10.1111/jbfa.12179

Datta, K. D., \& Puia, G. (1995). Cross-border acquisitions: An examination of the influence of relatedness and cultural fit on shareholder value creation in US acquiring firms. Management International Review, 35(4), 337-357.

Davis, E., Shore, G., \& Thompson, D. (1991). Continental mergers are different. Business Strategy Review, 2(1), 49-70. https://doi.org/10.1111/j.1467-8616.1991.tb00147.x

De Bondt, F. M. W., \& Thaler, R. (1985). Does the stock market overreact. The Journal of Finance, 40(3). https://doi.org/10.1111/j.1540-6261.1985.tb05004.X

Dimson, E., \& Marsh, P. (1999). Murphy's law and market anomalies. Journal of Portfolio Management, 25(2), 53-69. https://doi.org/10.3905/jpm.1999.319734

Draper, P., \& Paudyal, K. (2006). Acquisitions: private versus public. European Financial Management, 12, 57-80. https://doi.org/10.1111/j.1354-7798.2006.00310x

Dutta, S., \& Jog, V. (2009). The long-term performance of acquirer firms: A re-examination of an anomaly. Journal of Banking and Finance, 33, 1400-1412. https://doi.org/10.1016/j.jbankfin.2009.02.004

Engle, F. R. (2001). The use of ARCH/GARCH models in applied econometrics. Journal of Economic Perspectives, 15, 157-168. https://doi.org/10.1257/jep.15.4.157

Engle, R. F., \& Ng, V. K. (1993). Measuring and testing the impact of news on volatility. Journal of Finance, 48, 1749-1778. https://doi.org/10.2307/2329066

Eun, S. C., \& Resnick, G. B. (2009). International financial management (5th ed.). McGraw-Hill/Irwin. 
International Edition.

Fama, E. F. (1998). Market efficiency, long-term returns, and behavioral finance. Journal of Financial Economics, 49, 283-306. https://doi.org/10.1016/0304-405x(98)00026-9

Fama, F. E., \& French, R. K. (1987). Dividend yields and expected stock returns. Working Paper. Chicago: University of Chicago.

Fama, F. E., \& French, R. K. (1992). The cross-section of expected stock returns. The Journal of Finance, 47(2). https://doi.org/10.2307/2329112

Fama, F. E., \& French, R. K. (1993). Factors in the returns of stocks and bonds. Journal of Financial Economics, 33, 3-56. https://doi.org/10.1016/0304-405x(93)90023-5

Fama, F. E., \& French, R. K. (1996). Multifactor explanations of asset pricing anomalies. Journal of Finance, 51, 55-84. https://doi.org/10.1111/j.1540-6261.1996.tb05202.x

Fatemi, A. M., \& Furtado, P. E. H. (1984). Shareholder benefits from corporate international diversification. Journal of Finance, 39(5), 1325-1344. https://doi.org/10.1111/j.1540-6261.1984.tb04910.x

Felin, T., \& Foss, N. J. (2009). Organizational routines and capabilities: Historical drift and a course-correction toward micro foundations. Scandinavian Journal of Management, 25(2), 157-167. https://doi.org/10.1016/j.scaman.2009.02.003

Field, L. C., \& Karpoff, M. J. (2002). Takeover defences of IPO firms. Journal of Finance, 57, $1857-1889$. https://doi.org/10.1111/0022-1082.00482

Fletcher, J., \& Forbes, D. (2002). An exploration of the persistence of UK unit trust performance. Journal of Empirical Finance, 9, 475-493. https://doi.org/10.1016/S0927-5398(02)00006-3

Foss, N. J. (2009). Alternative research strategies in the knowledge movement: From macro bias to microfoundations and multilevel explanation. European Management Review, 6(1), 16-28. https://doi.org/10.1057/emr.2009.2

Franks, J., Harris, R., \& Titman, S. (1991). The post-merger share-price performance of acquiring firms. Journal of Financial Economics, 29, 81-96. https://doi.org/10.1016/0304-405X(91)90014-B

Gan, C., Bian, C., Wu, D., \& Cohen, A. D. (2017). Determinants of share returns following repurchase announcements in China. Investment Management and Financial Innovations, 14(2), 4-18. https://doi.org/21511/imfi.14(2).2017.01

Giannopoulos, G., Khansalar, E., \& Neel, P. (2017). The impact of single and multiple mergers and acquisitions on shareholders' wealth of UK bidder firms. International Journal of Economics and Finance, 9(3). https://doi.org/10.5539/ijef.v9n3p141

Gibbons, M., \& Hess, P. (1981). Day of the Week Effects and Asset Returns. Journal of Business, 54, $579-596$. https://doi.org/10.1086/296147

Glosten, R. L., Jagannathan, R., \& Runkle, E. D. (1993). On the relation between the expected value and the volatility of the nominal excess return on stocks. Journal of Finance, 48(6). https://doi.org/10.1111/j.1540-6261.1993.tb05128.x

Goddard, J., Molyneux, P., \& Zhou, T. (2012). Bank mergers and acquisitions in emerging markets: Evidence from Asia and Latin America. The European Journal of Finance, 18(5), 419-438. https://doi.org/10.1080/1351847x.2011.601668

Gregory, A., \& McCorriston, S. (2005). Foreign acquisitions by UK limited companies: Short and long-run performance. Journal of Empirical Finance, 12, 99-125. https://doi.org/10.1016/j.jempfin.2003.10.003

Grinblatt, M., \& Titman, J. S. (2002). Financial markets and corporate strategy. Published by McGraw-Hill / Irwin, Boston, MA.

Haleblian, J., Devers, C. E., McNamara, G., Carpenter, M. A., \& Davison, R. B. (2009). Taking stock of what we know about mergers and acquisition: A review and research agenda. Journal of Management, 35(3), 469-502. https://doi.org/10.1177/0149206308330554

Haugen, R., \& Jorion, P. (1996). The January effect: still there after all these years. Financial Analysts Journal, 52, 27-31. https://doi.org/10.2469/faj.v52.n1.1963

Healey, M. P., Palepu, G. K., \& Reback, S. R. (1992). Does corporate performance improve after mergers? 
Working Paper. https://doi.org/10.1016/0304-405X(92)90002-F

Heron, R., \& Lie, E. (2002). Operating performance and the method of payment in takeovers. Journal of Financial and Quantitative Analysis, 37(1). https://doi.org/10.2307/3594998

Higson, C., \& Elliott, J. (1998). Post-Itakeover returns: The UK evidence. Journal of Empirical Finance, 5, 27-46. https://doi.org/10.1016/50927-5398(96)00015-1

Hogholm, K. (2016). Bidder's gain in public M\&A transactions: Does size matter? International Journal of Economics and Finance, 8(5). http://dx.doi.org/10.5539/ijef.v8n5p1

Holl, P., \& Kyriazis, D. (1997). Wealth creation and bid resistance in UK takeover bids. Strategic Management Journal, $18(6)$ 483-498. https://doi.org/10.1002/(SICI)1097-0266(199706)18:6<483::AID-SMJ895>3.0.CO;2-6

Hong, H., \& Stein, J. (1999). A unified theory of underreaction, momentum trading and overreaction in asset markets. Journal of Finance, 54, 2143-2184. https://doi.org/10.1111/0022-1082.00184

Jandik, T., \& Lallemand, J. (2017). Do capital structure adjustments by takeover targets influence acquisition gains? The Financial Review, 52, 171-198. https://doi.org/10.1111/fire.12134

Jarrell, G. A., \& Poulsen, A. B. (1989). The returns to acquiring firms in tender offers: Evidence from 3 decades. Financial Management, 18(3), 12-19. https://doi.org/10.2307/3665645

Jegadeesh, N. (1990). Evidence of predictable behaviour of security returns. Journal of Finance, 45, 881-898. https://doi.org/10.1111/j.1540-6261.1990.tb05110.x

Jegadeesh, N., \& Titman, S. (1993). Returns to buying winners and selling losers: Implications for stock market efficiency. The Journal of Finance, 48(1). https://doi.org/10.1111/j.1540.6261.1993.Tb04702.x

Jegadeesh, N., \& Titman, S. (2001). Profitability of momentum strategies: An evaluation of alternative explanations. Journal of Finance, 56(2). https://doi.org/10.1111/0022-1082.00342

Jensen C. M., \& Ruback, S. R. (1983). The market for corporate control: The scientific evidence. Journal of Financial Economics, 11, 5-50. https://doi.org/10.1016/0304-405X(83)90004-1

Karim, S., \& Mitchell, W. (2000). Path-dependent and path-breaking change: Reconfiguring business resources following acquisitions in the US medical sector, 1978-1995. Strategic Management Journal, 21(10/11), 1061-1081. https://doi.org/10.1002/1097-0266(200010/11)21:10/11<1061::AID-SMJ116>3.0.CO;2-G

Kemal, M. (2011). Post-merger profitability: A case of Royal Bank of Scotland. International Journal of Business and Social Science, 2(5), 157-16.

Kolari, J. W., \& Pynnönen, S. (2010). Event study testing with a cross-sectional correlation of abnormal returns. Review of Financial Studies, 23(11), 3996-4025. https://doi.org/10.1093/rfs/hhq072

Kothari, P. S., \& Warner, B. J. (1997). Measuring long-horizon security price performance. Journal of Financial Economics, 43, 301-339. https://doi.org/10.1016/50304-405x(96)0899-9

Kyei-Mensah, J., Su, C., \& Joseph, L. N. (2017). Shareholders wealth and mergers and acquisitions. Investment Management and Financial Innovations, 14(3), 15-24. https://doi.org/10.21511/imfi.14(3)2017.02

Lall, S. (1983). The new multinationals: The spread of third world enterprises. New York: Wiley. https://doi.org/10.1080/01436598308419716

Lang, L. H. P., Stulz, M. R., \& Walkling, R. A. (1989). Management performance, Tobin's q, and the gains from successful tender offers. Journal of Financial Economics, 24, 137-154. https://doi.org/10.1016/0340-405x(89)90075-5

Lewellen, J. (2002). Momentum and autocorrelation in stock returns. The Review of Financial Studies, 15(2). https://doi.org/10.1093/rfs/15.2.533

Lewis, D., \& Webb, R. J. (2007). Potential cost synergies from banks acquiring real estate brokerage services. Journal of Banking \& Finance, 31, 2347-2363. https://doi.org/10.1016/j.jbankfin.2006.09.012

Lo, W. A., \& MacKinlay, C. A. (1988). Stock market prices do not follow Irandom walks: Evidence from a simple specification test. The Review of Financial Studies, 1(1), 41-66. https://doi.org/10.1093/rfs/1.1.41

Lo, W. A., \& MacKinlay, C. A. (1990). When Are Contrarian Profits Due to Stock Market Overreaction? The Review of Financial Studies, 3(2), 175-205. https://doi.org/10.1093/rfs/3.3.431

Loughran, T., \& Ritter, R. J. (2000). Uniformly least powerful tests of market efficiency. Journal of financial 
Economics, 55, 361-389. https://doi.org/10.1016/50304-405x(99)00054-9

Loughran, T., \& Vijh, M. A. (1997). Do long-term shareholders benefit from corporate acquisitions? Journal of Finance, 52(5), 1765-1790. https://doi.org/10.2307/2329464

Marr Jr., W. M., Mohta, S., \& Spivey, F. M. (1993). An analysis of foreign takeovers in the United States. Managerial and Decision Economics, 14(4), 285-294. https://doi.org/10.1002/mde.4090140402

Meyer, E. K. (2018). Catch-up and leapfrogging: Emerging economy multinational enterprises on the global stage. International Journal of Economics and Business, 25(1), 19-30. https://doi.org/10.1080/13571516.2017.1374624

Mitchell, L. M., \& Stafford, E. (2000). Managerial decisions and long-term stock price performance. Journal of Business, 73(3). https://doi.org/10.1086/209645

Moeller, B. S., Schlingemann, P. F., \& Stulz, M. R. (2004). Firm size and the gains from Acquisitions. Journal of Financial Economics, 73, 201-228. https://doi.org/10.1016/j.jfineco.2003.07.002

Mohamad, A., Jaafar, A., Hodgkinson, L., \& Wells, J. (2013). Short selling and stock return: Evidence from the UK. The British Accounting Review, 30, 1-13. https://doi.org/10.1016/j.bar.2013.03001

Morck, R., \& Yeung, B. (1992). Internalizational: an event study test. Journal of International Economics, 33, 41-56. https://doi.org/10.1016/0022-1996(92)90049-P

Mueller, D. C., \& Sirower, M. L. (2003). The causes of mergers: Tests based on the gains to acquiring firm's shareholders and size of premia. Managerial and Decision Economics, 24, 373-391. https://doi.org/10.1002/mde.1103

Myers, S. C., \& Majluf, N. S. (1984). Corporate financing and investment decisions when firms have information that investors do not have. Journal of Financial Economics, 13(2), 187-221. https://doi.org/10.1016/0304-405x(84)90023-0

Napier, N. K. (1989). Mergers and acquisitions, human resource issues and outcomes: A review and suggested $\begin{array}{lllll}\text { typology. Journal of } & \text { Management 26(3), }\end{array}$ https://doi.org/10.1111/j.1467-6486.1989.tb00728.x

Nelson, D. (1991). Conditional heteroscedasticity in asset returns: A new approach. Econometrica, 59, 347-370. https://doi.org/10.2307/2938260

North, S. D. (2001). The role of managerial incentives in corporate acquisitions: The 1990s evidence. Journal of Corporate Finance, 7, 125-149. https://doi.org/10.1016/S0929-1199(01)00017-7

Osareh, F. (1996). Bibliometrics, citation analysis and co-citation analysis: A review of literature 1. Libri, 46(3), 149-158. https://doi.org/10.1515/libr.1996.46.3.149

Palepu, K. G. (1986). Predicting Takeover Targets. Methodological and empirical analysis. Journal of Accounting and Economics Vol. 8, pp. 3-35. https://doi.org/0156-4101(86)90008.x

Powell, G. R., \& Stark, W. A. (2006). Does operating performance increase post-takeover for UK takeovers? A comparison of performance measures and benchmarks. Journal of Corporate Finance, 11, 293-317. https://doi.org/j.jcorpfin.2003.06.001

Ranft, L. A., \& Lord, D. M. (2002). Acquiring new technologies and capabilities: A grounded model of acquisition implementation. Organization $\quad$ Science, $13(4), \quad 420-441$. https://doi.org/10.1287/orsc.13.4.4202952

Rege, P. U. (1984). Accounting ratios to locate take-over targets. Journal of Business Finance and Accounting, 11(3). https://doi.org/10.1111/j.1468-5957.1984.tb00751.x

Reinganum, M. R. (1999). The significance of market capitalization in portfolio management over time. Journal of Portfolio Management, 25, 39-50. https://doi.org/10.3905/jpm.1999.319750

Reynolds, N. S., \& Teerikangas, S. (2016). The international experience in domestic mergers- are purely domestic M\&As a myth. International Business Review, 25, 42-50. https://doi.org/10.1016/j.ibusrev.2015.07.002

Roll, R. (1986). The hubris hypothesis of corporate takeovers. Journal of Business, 59, 197-216. https://doi.org/10.1086/296325

Rosen, J. R. (2006). Merger momentum and investor sentiment: The stock market reaction to merger 
announcements. The Journal of Business, 79(2), 987-1017. https://doi.org/10.2139/ssrn.343600

Sarig, H. O., \& Talmor, E. (1997). In defence of defence measures. Journal of Corporate Finance, 3, 277-297. https://doi.org/10.1016/S0929-1199(96)00016-8

Savor, G. P., \& Lu, Q. (2009). Do stock mergers create value for acquirers? The Journal of Finance, 64(3). https://doi.org/10.1111/j.1540-6261.2009.01459.x

Shafique, M. (2013). Thinking inside the box? Intellectual structure of the knowledge base of innovation research (1988-2008). Strategic Management Journal, 34(1), 62-93. https://doi.org/10.1002/smj.2002

Sudarsanam, S., \& Mahate, A. A. (2003). Glamour acquirers, method of payment and post-acquisition performance: The UK evidence. Journal of Business Finance and Accounting, 30(1\&2), 299-341. https://doi.org/10.1111/1468-5957.00494

Sudarsanam, S., \& Mahate, A. A. (2006). Are friendly acquisition too bad for shareholders and managers? Long-term value creation and top management turnover in hostile and friendly acquirers. British Journal of Management, 17, 7-30. https://doi.org/j.1467-8551.2006.00476.x

Travlos, G. N. (1987). Corporate takeover bids, methods of payment and bidding firms' stock returns. The Journal of Finance, 42(4), 943-963. https://doi.org/10.2307/2328300

Tuch, C., \& O'Sullivan, N. (2007). The impact of acquisitions on firm performance: A review of the evidence. International Journal of Management Reviews, 9(2), 141-170. https://doi.org/j.1468-2370.2007.00206.x

Uhlenbruck, K., Hughes-Morgan, M., Hitt, A. M., Ferrier, J. W., \& Brymer, R. (2018). Rivals' reactions to mergers and acquisitions. Strategic Organization, 15(1), 40-66. https://doi.org/10.1177/1476127016630526

Van Dijk, M. A. (2007). Is size dead? A review of the size effect in equity returns. Retrieved from http://ssrn.com/abstract=879282

Walker, M. M. (2000). Corporate takeovers, strategic objectives, and acquiring firm shareholder wealth. Financial Management, 29(1), 53-66. https://doi.org/10.2307/3666361

Wang, X. (2000). Size effect, book-to-market effect, and survival. Journal of Multinational Management, 10, 257-273. https://doi.org/10.1016/S1042-444x(00)00033-5

Weston, J. F., Siu, J. A., \& Johnson, B. A. (2001). Takeovers, restructuring \& corporate governance (3rd ed.). Prentice-Hall, Inc.

Wu, X., Yang, X., Yang, H., \& Lei, H. (2016) Cross-border mergers and acquisitions by Chinese firms: Value creation or value destruction? Journal of Contemporary China, 25(97), 130-145. https://doi.org/10.1080/10670564.2015.1060769

Yen, T., \& Andre, P. (2010). The effect of the ownership structure of acquiring firms. Journal of Business Policy Research, 5, 5976.

Zander, U., \& Zander, L. (2010). Opening the grey box: Social communities, knowledge, and culture in acquisitions. Journal of International Business Studies, 41, 27-37. https://doi.org/10.1057/jibs.2009.76

\section{Copyrights}

Copyright for this article is retained by the author(s), with first publication rights granted to the journal.

This is an open-access article distributed under the terms and conditions of the Creative Commons Attribution license (http://creativecommons.org/licenses/by/4.0/). 